\title{
VARIAN PANGAN OLAH BERBASIS KELAPA DI DESA JERUJU BESAR KALIMANTAN BARAT
}

\author{
Variant of Coconut Based Food in Jeruju Besar Village West Kalimantan
}

\author{
Muflihah Ramadhia dan Abdullah \\ Politeknik Negeri Pontianak, Jurusan Teknologi Pertanian dan Administrasi Bisnis, Jalan Jenderal \\ Ahmad Yani Pontianak, Kalimantan Barat \\ email : ramadhia99@yahoo.com
}

\begin{abstract}
This activity aims to empower the PKK group and group farmer Desa Jeruju Besar with the growth of motivation, knowledge, skills, and new skills to produce variants of coconut-based products and generate entrepreneurial spirit to become edukatif human beings in viewing their potential to be used as a variatif, Inofativ and high selling power. Specific targets to be achieved are partnerships have qualified human resources in the process and management systems, a description of the business to be done, directional and trained managerial skills and the formation of creative partners. The method used in the achievement of the intended purpose is done in two stages, namely the a) the delivery of information to the local potential owned by Jeruju Besar Village to create a variation of coconut-based product if the model has high selling value and information on the importance of entrepreneurship to improve knowledge, Skills and family earnings theoretically for the purpose of understanding the activity. Stage b) demonstration of the manufacture of variants of coconut-based products include: equipment operation, processing, storage and packaging followed by training techniques on the ability to initiate new business which includes bookkeeping procedures, product marketing techniques and management and introduction of new products created Of the target market.
\end{abstract}

Keywords: variants, product though, partners and business management

\begin{abstract}
ABSTRAK
Kegiatan ini bertujuan memberdayakan kelompok PKK dan Kelompok Tani Desa Jeruju Besar dengan penumbuhan motivasi, pengetahuan, keterampilan, serta keahlian baru untuk menghasilkan varian produk olah berbasis kelapa dan membangkitkan jiwa berwirausaha untuk menjadi manusia beredukatif dalam melihat potensi yang dimiliki untuk dijadikan produk yang variatif, keratif, inofativ dan daya jual tinggi. Target khusus yang ingin dicapai yaituMitra memiliki sumber daya manusia yang qualified dalam proses olah dan sistem manajemen, gambaran tentang usaha yang akan dilakukan, kemampuan managerial terarah dan terlatih serta terbentuknya mitra yang kreatif. Metoda yang dipakai dalam pencapaian tujuan yang dimaksud dilakukan dalam dua tahapan, yaitu Tahap a) penyampaian informasi terhadap potensi lokal yang dimiliki oleh Desa Jeruju Besar untuk dilakukan penciptaan varian produk olah berbasis kelapa yang memiliki nilai jual tinggi serta informasi mengenai pentingnya kewirausahaan untuk meningkatkan pengetahuan, keterampilan dan penghasilan keluarga secara teoritis untuk pemudahan pemahaman kegiatan. Tahap b) pendemonstrasian pembuatan varian produk olah berbasis kelapa meliputi: pengoperasian alat, pengolahan, penyimpanan dan pengemasan yang dilanjutkan dengan teknik pelatihan terhadap kemampuan untuk melakukan pemulaian bisnis baru yang mencakup tata cara pembukuan, teknik dan manajemen pemasarn produk serta pengenalan terhadap produk baru yang diciptakan terhadap pasar yang akan dituju.
\end{abstract}

Kata Kunci: varian, produk olah, mitra dan manajemen usaha 


\section{PENDAHULUAN}

Desa Jeruju Besar merupakan sebuah desa yang terletak di Kecamatan Sungai Kakap Kabupaten Kubu Raya Provinsi Kalimantan Barat. Wilayah Desa Jeruju Besar sebelah Utaranya berbatasan dengan Desa Sungai Kupah, sebelah Selatan berbatasan dengan Desa Sungai Itik, sebelah Barat berbatasan dengan Laut Natuna dan sebelah Timur berbatasan dengan Desa Sungai Rengas. Jarak antara Desa Jeruju Besar dengan Politeknik Negeri Pontianak adalah sekitar $40 \mathrm{~km}$ (Sekretaris Desa, 2015-2016). Saat ini, wilayah Jeruju Besar di pimpin oleh Ibu Nur Halijah, SE. Data yang diperoleh menyimpulkan bahwa wilayah ini memiliki luas areal tanaman kelapa sebesar 2969 Ha dengan hasil buah kelapa 444 ton/ Ha. Menurut Kepala Desa, rendah dan minimnya pendidikan, serta keterbatasan sarana prasarana dan minimnya informasi perkembangan industri merupakan faktor penyebab belum adanya hilirisasi produk, sehingga tengkulak merajelela dalam menentukan harga. Efek langsung yang dapat dirasakan oleh warga setempat adalah kerugian karena biaya operasional yang tinggi tidak sebanding dengan jumlah rupiah yang mereka dapatkan.

Penjelasan yang telah diuraikan mengenai Desa Jeruju Besar yang memiliki potensi besar dalam bidang pertanian, sehingga sangat mungkin untuk dilakukan pengembangannya, namun minim pendampingan merupakan permasalahan yang harus diberikan solusi, mengingat desa Jeruju Besar merupakan sentra olahan kelapa bagi Kalimantan Barat dan memiliki kelompok aktif yang dapat dibina untuk pengembangan menuju hilirisasi. Penelitian mengenai olahan kelapa telah diungkapkan, diantaranya oleh Yuliani (2011), selai tempurung kelapa memiliki nutrisi posistif bagi tubuh. Menurut Sindumathi dan Amutha (2014), sebagai makanan fungsional, kelapa memiliki lemak asam yang menyediakan energi dan bahan baku untuk aktivitas antimikroba dan monogliserida. asam laurat, yangutama hadir asam lemak dalam kelapa, telah diakui untuk antivirus nya, antibakteri dan antiprotozoal dan menurut Alleyne (2005), air kelapa adalah sumber makanan terkaya alami sitokinin dan mengkonsumsi sumber yang kaya sitokinin, seperti air kelapa, bisa menghasilkan efek anti-penuaan pada tubuh, mengurangi risiko mengembangkan penyakit degeneratif dan usia terkait.

Kelompok PKK yang ditunjuk adalah kelompok PKK Desa Jeruju Besar yang memiliki jumlah anggota 43 orang dengan beragam profesi yang dimiliki dan Kelompok Wanita Tani yang berjumlah 58 orang. Kelompok ini ditunjuk sebagai mitra karena dinilai dapat mengembangkan potensi yang dimiliki menjadi bentuk usaha baru hilirisasi, sehingga dapat mengangkat harkat, martabat dan kehidupan kelompok warga Desa Jeruju Besar.

\section{BAHAN DAN METODE}

\section{Bahan}

Bahan yang digunakan pada kegiatan pengabdian masyarakat meliputi; kelapa muda, kelapa tua, air kelapa tua, margarine, telur, terigu, coco chips, kelapa parut kering, essence, gula pasir, pewarna, roti tawar, rempah-rempah, gula merah, keju, gula halus, pectin, garam,,penyedap rasa, minyak goring, butter, susu bubuk dan susu kental manis.

\section{Alat}

Alat yang digunakan pada kegiatan pengabdian masyarakat meliputi: oven, loyang, mixer, blender, cup sealer, sealer, kompor gas, baskom, nampan, pencetak, panci pengkus, perebus, sendok, parang, sutil, penyerok, teko ukur, timbangan, serbet, tissue, garpu, toples, piring, cup sirup, cup selai, spatula, plastik PP dan plastik PE. 


\section{Metode Pelaksanaan}

Metode pelaksanaan kegiatan pengabdian masyarakat dibagi menjadi dua komponen penting yang mencakup a) sistem penyampaian informasi secara teoritis dengan teknik penyampaian teori langsung kepada mitra dalam bentuk presentasi di dalam forum diskusi antara pengusul kegiatan dan mitra. b) penyampaian teknik olah dengan sistem demonstrasi. Demonstrasi dilakukan terhadap seluruh kreasi olah yang sudah disepakati hingga sampai produk jadi yang dilanjutkan dengan pembuatan pembukuan keuangan sederhana terhadap produk yang diusahakan, serta teknik berkomunikasi dengan calon konsumen terkait mengenalkan produk baru yang mereka hasilkan, serta mencari peluang dimana produk tersebut akan dijual.

\section{HASIL DAN PEMBAHASAN}

Hasil

Pengabdian ini menghasilkan enam (6) produk olahan pangan berbahan kelapa. Sebelum dan sesudah kegiatan, dilakukan pengisian kuisioner untuk 25 peserta yang mengikuti kegiatan. Data yang diperoleh berdasarkan penyebaran kuisioner di sajikan pada Tabel 1, 2 dan 3.

Tabel 1. Data kuisioner sebelum kegiatan

\begin{tabular}{ccccccc}
\hline Produk & $\begin{array}{c}\text { Kelapa } \\
\text { parut } \\
\text { kering }\end{array}$ & Kecap & $\begin{array}{c}\text { Ice } \\
\text { cream }\end{array}$ & Selai & sirup & Biskuit \\
\hline Peserta terampil & 0 & 5 & 0 & 3 & 5 & 2 \\
$\begin{array}{c}\text { Peserta tidak } \\
\text { Terampil }\end{array}$ & 25 & 20 & 25 & 22 & 20 & 23 \\
\hline
\end{tabular}

Tabel 2. Data kuisioner setelah kegiatan

\begin{tabular}{ccccccc}
\hline Produk & $\begin{array}{c}\text { Kelapa } \\
\text { parut } \\
\text { kering }\end{array}$ & Kecap & $\begin{array}{c}\text { Ice } \\
\text { cream }\end{array}$ & Selai & sirup & Biskuit \\
\hline Peserta terampil & 25 & 25 & 25 & 25 & 25 & 25 \\
$\begin{array}{c}\text { Peserta tidak } \\
\text { Terampil }\end{array}$ & 0 & 0 & 0 & 0 & 0 & 0 \\
\hline
\end{tabular}

Tabel 3. Pendapat peserta tentang produk yang dihasilkan

\begin{tabular}{lcccccc}
\hline \multicolumn{1}{c}{ Produk } & $\begin{array}{c}\text { Kelapa } \\
\text { parut } \\
\text { kering }\end{array}$ & Kecap & $\begin{array}{c}\text { Ice } \\
\text { cream }\end{array}$ & Selai & sirup & Biskuit \\
\hline Keterangan peserta & 25 & 20 & 25 & 20 & 25 & 8 \\
TMBE & 0 & 5 & 1 & 5 & 0 & 17 \\
\hline
\end{tabular}

Keterangan :

MBE adalah menarik dan bernilai ekonomi

TMBE adalah tidak menarik dan tidak bernilai ekonomis 

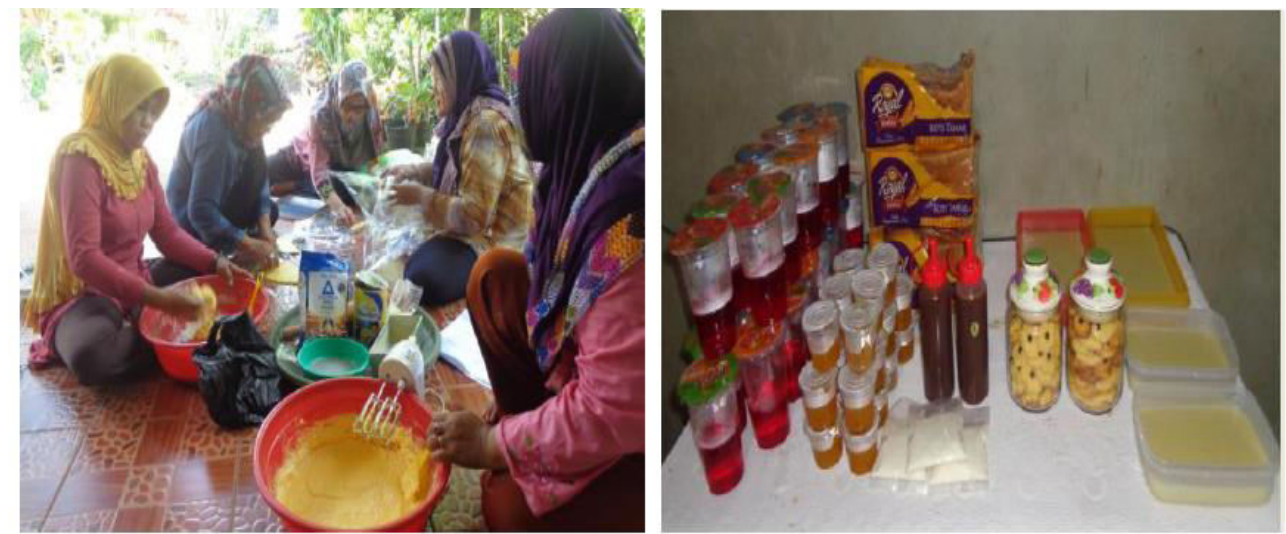

Gambar.1 Kegiatan produksi dan 6 produk yang dihasilkan

\section{Pembahasan}

Pengabdian masyarakat yang dilakukan di Desa Jeruju Besar dengan bantuan dana DIKTI menjadi moment bagi warga desa yang tergabung dalam kelompok PKK dan Kelompok Tani Desa Jeruju Besar dalam memperoleh ilmu praktik secara informal dalam hal olahan pangan berbasis kelapa menjadi industri hilir. Harapan yang ingin dicapai dan diperoleh adalah kelompok warga yang dibina memiliki keterampilan olah secara menyeluruh baik dalam sistem produksi maupun sistem manajemen yang dibutuhkan dalam pembukaan usaha baru untuk meningkatkan nilai ekonomi masyarakat desa setempat umumnya.

Berdasarkan data pada Tabel 1, maka $85 \%$ peserta tidak paham dan tidak terampil dalam sistem olah pangan yang dikenalkan, bahakan terdapat beberapa peserta belum mengenal produk yang di latihkan, namun setelah kegiatan dimulai jumlah peserta yang tidak kenal, tidak paham dan tidak tertarik sangat jauh berbeda, dimana seluruh peserta terampil dalam melakukan olahan produk yang dilatihkan (Tabel 2). Terdapat enam produk yang dihasilkan pada pengabdian ini yaitu kelapa parut kering; spesifikasi warna putih,kering, bau harum, kecap air kelapa; spesifikasi konsistensi kental, warna coklat kehitaman, rasa manis segar, aroma khas kecap, es krim kelapa; spesifikasi warna transparan, rasa manis, aroma kelapa, sirup kelapa: spesifikasi aroma khas kelapa, warna transparan, selai kelapa; spesifikasi transparan, rasa manis,mudah dioles pada roti dan biskuit kelapa; spesifikasi renyah, menarik dan berasa manis.

Keterampilan dan keahlian yang diperoleh peserta dimulai dari sistem olah pangan dalam berproduksi yaitu mulai dari pengenalan jenis bahan yang dapat dan tidak digunakan, efisiensi penggunaan bahan, serta tahapan olah seluruh produk yang dilatihkan. Sistem olah dilanjutkan dengan teknik mengemas produk yang dihasilkan. Pemilihan bahan kemas yang cocok serta desain produk yang menarik juga telah dilatihkan dan dapat dilakukan secara mandiri oleh peserta. Keterampilan lanjutan yang diberikan adalah sistem manajemen usaha, dimana peserta mampu melakukan sistem koordinasi keuangan sederhana terhadap usaha yang dilakukan, sehingga dapat menghitung rugi laba secara tertulis. Teknik promosi produk baru baik secara manual maupun menggunakan media social yaitu melaui face book dan whatapps.

\section{KESIMPULAN}

Berdasarkan evaluasi tim pelaksana kegiatan pengabdian kepada masyarakat, maka dapat disimpulkan:

1. Peserta memiliki kemauan untuk belajar, maju dan berkembang, hal ini dibuktikan dengan jumlah peserta yang datang dan tingkat keseriusan dalam berlatih.

2. Peserta/mitra dapat memahami seluruh tahapan produksi sistem olah produksi yang dilatihkan. 
3. Peserta/mitra dapat memahami seluruh tahapan sistem manajemen usaha yang dilatihkan

\section{DAFTAR PUSTAKA}

Alleyne, T., (2005). The control of hypertension by use of coconut water and mauby: two tropical food drinks. West Indian Med Journal, 54:3-8.

Seketaris Desa. (2015). Profil Desa Jeruju Besar. Pemerintah Kabupaten Kubu Raya Kecamatan Sungai Kakap. Kalimantan Barat.
Sindumathi,G dan Amutha, S. (2014). Processing and quality evaluation of coconut based jam. IOSR Journal Of Environmental Science, Toxicology And Food Technology, 8(1) Ver. I.

Yuliani, R. (2011). Karakterisasi Selai Tempurung Kelapa Muda. Prosiding Seminar Nasional Teknik Kimia Pengembangan Teknologi Kimia untuk Pengolahan Sumber Daya Alam Indonesia. 